\title{
Grapheme-Phoneme Conversion in Korean Word Recognition: Evidence from Event-Related Potentials
}

\author{
Sou Jin Choi, Hyun Sub Sim \\ Department of Communication Disorders, Ewha Womans University, Seoul, Korea
}

Correspondence: Hyun Sub Sim, PhD Department of Communication Disorders, Ewha Womans University, 52 Ewhayeodae-gil, Seodamun-gu, Seoul 03760, Korea

Tel: $+82-2-3277-3538$

Fax: +82-2-3277-2122

E-mail: simhs@ewha.ac.kr

Received: July 5, 2019

Revised: August 6, 2019

Accepted: August 19, 2019

This work was supported by the BK21Plus funded by the National Research Foundation of Korea (NRF-1-2019-0405-001-1).
Objectives: Although Hangul, the Korean alphabet, is orthographically shallow, the phonological rules cause difficulties for dyslexic children in reading and writing. We investigated the difference in grapheme-phoneme conversion (GPC) of Korean words and nonce words when phonological rules are applied. Based on the dual route theory, we tried to explain the activation of the GPC route. Methods: We recorded EEGs from 28 native Korean adults while they were conducting a phoneme judgment task in which they were asked to decide whether the pronunciation of the visual word was identical to the corresponding auditory word. Response accuracy rate, reaction time, and N250 waveforms were analyzed for phonological processing in word recognition. Results: For the mean response accuracy rates and reaction times of the phoneme judgment task, there was a significant main effect of the stimulus word category and of the applied rules. The event-related potential (ERP) showed significantly smaller amplitude of N250 in words than in nonce-words. Specifically, for the words, the N250 waveform was smaller in incorrect pronunciation than with correct pronunciation. However, there was no significant effect in nonce words. Conclusion: The result provides support for the dual route model of reading and writing. In Korean word recognition, people automatically apply phonological rules with familiar words, however, GPC causes a delay when recognizing unfamiliar words.

Keywords: Phonological processing, N250, Dyslexia, Word recognition, Grapheme-phoneme conversion, Dual Route model
Word recognition refers to the basic ability to connect letters and phonemes to read words correctly and the difficulty in acquiring these decoding skills results in reading disabilities (Hallahan, Lloyd, Kauffman, Weiss, \& Martinez, 2005). Many studies have examined the real-time process of word recognition by analyzing phonological characteristics in different languages and made attempts to use the results for the therapeutic interventions of language disorders. McPherson, Ackerman, Holcomb, and Dykman (1998) have revealed the phonological processing ability of reading disabled adolescents by conducting a rhyme task to identify the area and the characteristics of their brain. And Moura, Moreno, Pereira, and Simões (2015) demonstrated that reading difficulty in dyslexic children are caused by the impairment of phonological processing. Bonte and Blomert (2004) found from their event-related potentials (ERP) study that dyslexics differ from normal readers in phonetic/phonological processing. Saralegui et al. (2014)'s functional magnetic resonance imaging (fMRI) study has shown that children with dyslexia have an impaired phonological route and compensate this disability by activating the orthographical route in both hemispheres.

As nonce words are known to go through the grapheme-to-phoneme conversion (GPC) route which is different from words, the comparison between words and nonce words is necessary in order to examine the phonological process of word recognition based on the dual route theory (Coltheart, 2006). Dyslexic children with impairment in the phonological route typically show greater diffi- 
culties in reading irregular words over regular words, and in nonce words over words (Landerl, Wimmer, \& Firth, 1997; Wagner \& Torgesen, 1987). Dyslexia in adults with brain damage, which might be due to the damage of phonological pathways, is also characterized by greater difficulty in reading non-words (Cho \& Pyun, 2015). The reading accuracy of children became more decreased when reading non-words than words (Yoon, Kim, \& Pae, 2011).

Korean is known as a language that is easy to read and write with sound-to-spelling consistency. Although Hangul, the Korean alphabet, is orthographically shallow, it has phonological rules which change its sounds when specific consonants meet together between syllabic blocks. For example, in the word '관리', the adjacent consonants of coda ' $L$ ' and onset 'ᄅ' have phonemic constraints which cause a phonemic change in sound-to-spelling. ' $L$ ' always represents the sound /n/ but when it is neighbored with 'ᄅ', the sound is changed into /1/. To be more specific, the word is supposed to sound /kwan-li/ but under the phonological rules, it will sound /kwal-li/. Those phonological rules cause difficulties in learning reading and writing, especially for dyslexics.

Recently, there have been ERP studies on phonological activation in Korean visual word recognition (Kwon, Nam, \& Lee, 2015) and on the use of orthographic information in spoken word recognition (Kwon, Choi, \& Lee, 2016) in healthy adults. In a study of Kwon et al. (2015), the amplitude of the N250 was smaller when the prime was orthographically or phonologically similar to the target. Kwon et al. (2016)'s study found that N320 was influenced by consistency of sound-to-spelling. These studies show that in Korean, even though its alphabet has strong consistency in spelling-to-sound, phonological processing of GPC is important in word recognition. However, there have not been any studies directed at the differences between word and nonce word recognition in Korean.

ERP helps to capture neural activity related to cognitive process and is useful to prove language processing in real-time (Picton et al., 2000). N250 waveform seems to be related with the GPC in the initial process of word recognition. It is known to represent the early processing (phonological or orthographical process) before the lexical access in word recognition. It is a negative peak which appears around $250 \mathrm{~ms}$ after the target. Previous studies showed that the amplitude of the N250 is found to be smaller in a phono- logically similar condition (Holcomb \& Grainger, 2006), and N270 appears clearly in the nonce word which has the same phoneme but different spelling (Connolly, Phillips, \& Frobes, 1995; Newman \& Connolly, 2004).

The purpose of this study is to investigate whether there are ERP differences between Korean words and nonce words in GPC when phonological rules are applied. For this purpose, the current study used the 220-320 ms time window where N250 and N270 are found to reveal the GPC in word recognition. This study tries to explain the different effects of words and nonce words on the activation of GPC route based on the dual route theory.

\section{METHODS}

\section{Participants}

A total of 28 native Korean adults ( 9 males and 19 females; mean age, 26.5 years; range, 21-38 years) who had completed higher education (15.57 \pm 1.26 years) participated in the research. All were right-handed and answered the questionnaire indicating that they had no history of neurological disorders and language disorders. They were all screened for normal hearing and normal or corrected-to-normal vision before starting the experiment.

\section{Stimulus Words}

A total of 204 two-syllable words (102 words and 102 nonce words) with phonological rules were selected for the experiment. One hundred two familiar words were selected from the wordlist of General Language Statistics of National Institute of Korean Language (2005) and elementary Korean language textbooks. One hundred two nonce words were selected from the study of Lee and Kim (2003) and Yi (1996). Half of the words and nonce words were recorded in proper pronunciation applying the phonological rules, and the other half were recorded with pronunciation that did not follow the phonological rules. In this way, the total 204 auditory items were divided into four conditions: (1) 51 words with correct pronunciation which were inconsistent in spelling-to-sound; (2) 51 words with incorrect pronunciation which were consistent spellingto-sound; (3) 51 nonce words with correct pronunciation which were inconsistent in spelling-to-sound; and (4) 51 nonce words with incorrect pronunciation which were consistent spelling-to-sound. 


\section{Sound Recording of Auditory Stimulus Words}

All the auditory stimuli used in the experiment were recorded by a female announcer with a digital recorder (Edirol R-09HR Digital Recorder) in a soundproof room. Items were saved in the recorder and automatically digitized at a sampling rate of $96 \mathrm{kHz}$ with 24-bit analog-to-digital conversion. The mean acoustic duration was $798 \mathrm{~ms}$ (range, 577-746 ms) and its onset was used in measuring a reaction time (RT) and as the time lock in ERP analyses.

\section{Procedure}

The EEG recording was conducted in a soundproof and electrically shielded room. The participants were seated in front of a $24-$ inch LCD monitor and asked to judge whether the sound of the words were pronounced correctly or not. In the phoneme judgment task, participants were required to assess whether the phonological rule was applied correctly after comparing the pronunciation of the auditory word to the visual word prime. Each trial began with a 200-ms fixation symbol (+) and then presented the visual word for $500 \mathrm{~ms}$. The study (Weber-Fox, Spencer, Spruill, \& Smith, 2004) which used one syllable English word to reveal the phonological processing presented the word for $300 \mathrm{~ms}$ and the study (Ziegler, Benraiss, \& Besson, 1999) which used the semantic decision task presented the word for $800 \mathrm{~ms}$. After the visual word disappeared from the screen, a blank screen appeared for 3,000 ms whilst the corresponding auditory sample was presented. The participants were asked to press the blue button if they thought the pronunciation of the word or nonce word was correct, and press the red button if they thought the pronunciation of the word or nonce word was incorrect. Participants were asked to register their response as quickly and accurately as possible. There was a 1,500ms interval, following the participant's response, before the next word was presented. The design of the experiment is shown in Figure 1. The trials were randomized for each participant and the participants had 5 minutes of breaks after every 51 trials. The EPrime 2.0 software (Schneider, Eschman, \& Zuccolotto, 2002) was used to present the tasks and record the behavioral responses. The correct response rate (\%), the reaction time (ms), and the average amplitude $(\mu \mathrm{V})$ of ERP were measured during the evaluation of the applied rule of the pronunciation.

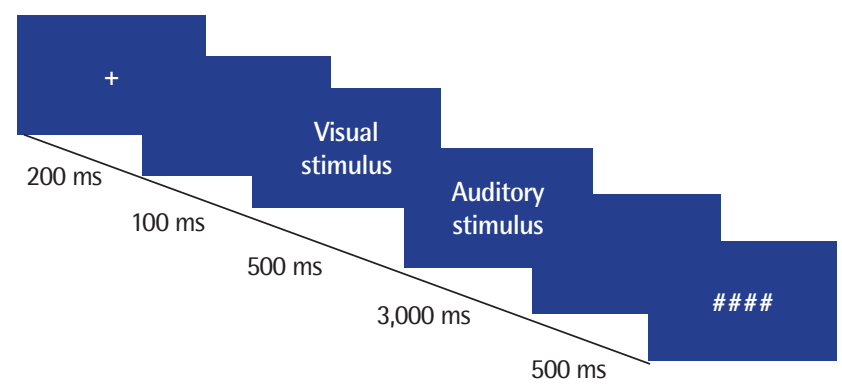

Figure 1. Design of phoneme judgment task.

\section{EEG Recording and Analysis}

The electroencephalography (EEG) data was recorded with a 32-channel actiCAP embedded with $\mathrm{Ag} / \mathrm{AgCl}$ electrodes based on the International 10-20 system via the Brain Vision BrainAmp Standard from Brain Products. The electrode below the right eye provided vertical electrooculogram (VEOG) and the electrodes over left and right mastoids served as offline reference. The EEG was amplified with 0.1 - to $100-\mathrm{Hz}$ band pass filters and digitized at a sampling rate of $500 \mathrm{~Hz}$. All electrodes impedances were kept below $10 \mathrm{k} \Omega$.

EEG data was analyzed using Brain Vision Analyzer 2.0.3 and the EEGLAB (Delorme \& Makeig, 2004) in MATLAB R2013b. The data from the correct responses were resampled to $250 \mathrm{~Hz}$ and a 0.01- to $30-\mathrm{Hz}$ band-pass filter was used. It was epoched from 200 ms before the onset of auditory stimulus to $800 \mathrm{~ms}$ after it. Artifacts greater than $\pm 50 \mu \mathrm{V}$ were excluded and were also removed by ocular correction. Mean amplitudes for latency window (220$320 \mathrm{~ms}$ after auditory stimuli onset) was used.

SPSS Statistics version 18 (SPSS Inc., Chicago, IL, USA) was used for statistical analysis and the electrodes were divided into four regions, anterior-left (FP1, F3, FC5, FC1, F7), anterior-right (FP2, F4, FC2, FC6, F8), posterior-left (CP5, CP1, P7, P3, O1), and posteriorright (CP2, CP6, P4, P8, O2). Statistical analysis in behavioral data of accuracy and RT was conducted in a two-way ANOVA using a $2 \times 2$ matrix with the following subject factors: the stimulus word category (word vs. nonce word); and applied rules (correct vs. incorrect). Statistical analysis in ERP data was conducted in a 4-way ANOVA using a $2 \times 2 \times 2 \times 2$ matrix with the following subject factors: stimulus word category, applied rule of pronunciation, laterality (left hemisphere vs. right hemisphere) and anteriority (anterior vs. posterior) for each time window. As word category is a 
Table 1. Accuracy and reaction times in words and nonce words

\begin{tabular}{lcr}
\hline & Accuracy (\%) & Reaction time (ms) \\
\hline Word & & \\
Correct & $95.7(4.0)$ & $981.5(152.8)$ \\
Incorrect & $87.4(8.2)$ & $1,045.8(181.0)$ \\
Nonce word & & \\
Correct & $90.8(6.0)$ & $1,054.3(199.4)$ \\
Incorrect & $78.4(11.1)$ & $1,107.5(230.3)$ \\
\hline
\end{tabular}

Values are presented as mean (SD).

pooled sample of words and nonce words in 4-way ANOVA, we additionally conducted 3-way ANOVAs for each of the word categories, word and nonce word, to see the effect of applying rules.

\section{RESULTS}

\section{Behavioral Results}

The mean response accuracy rates and RTs of the phoneme judgment task are presented in Table 1. Only correct responses were considered for the RTs in this analysis. Here a 2 (word vs. nonce word) $\times 2$ (correct vs. incorrect) ANOVA was conducted. For accuracy rate, there was a significant main effect of the stimulus word category $\left(F_{(1,27)}=67.594, p<.001\right)$ and of applied rules $\left(F_{(1,27)}=27.008\right.$, $p<.001)$. The two-way interaction between stimulus word category and applied rule approached significance $\left(F_{(1,27)}=11.307, p<.005\right)$, which means there was a greater difference of accuracy rate in nonce words when judging the correct and incorrect pronunciation than the difference of rule applying in judging words. For reaction time, there was a significant main effect of stimulus word category $\left(F_{(1,27)}=27.203, p<.001\right)$ and of applying rules $\left(F_{(1,27)}=20.264\right.$, $p<.001)$. There were no other effects significant in the reaction time. Regardless of the stimulus word category of the words, the gap of the reaction time between correct and incorrect pronunciation was similar.

\section{ERP Results: N250 (220-320 ms)}

Only correct responses of epochs were included for the analysis. Here a 4-way repeated 2 (word vs. nonce word) $\times 2$ (correct vs incorrect) $\times 2$ (anterior vs. posterior) $\times 2$ (right vs. left) ANOVA was conducted. The main effect of stimulus word category $\left(F_{(1,27)}=32.638\right.$, $p<.001)$, laterality $\left(F_{(1,27)}=9.552, p<.01\right)$, and anteriority $\left(F_{(1,27)}=\right.$
$15.935, p<.001)$ was significant. N250 effect was significantly larger in words than nonce words. Two-way interaction between word stimulus word category and anteriority was significant $\left(F_{(1,27)}=11.977\right.$, $p<.01)$. The difference between anterior and posterior in nonce words was significantly larger than in words. There were no other significant effects.

For the words, 3-way repeated ANOVAs (applied rule $\times$ laterality $\times$ anteriority) were conducted. The main effect of applied rule $\left(F_{(1,27)}=7.291, p<.05\right)$, laterality $\left(F_{(1,27)}=11.538, p<.01\right)$, anteriority $\left(F_{(1,27)}=8.751, p<.01\right)$ was significant. The $\mathrm{N} 250$ effect was larger in words with incorrect pronunciation than in words with correct pronunciation. There were no other effects significant for words. For the nonce words, 3-way ANOVAs (applied rule $\times$ laterality $\times$ anteriority) were conducted. The main effect of laterality $\left(F_{(1,27)}=\right.$ $7.274, p<.05)$ and anteriority $\left(F_{(1,27)}=22.203, p=.001\right)$ was significant. In contrast, pronunciation applied rule had no significant main effect $\left(F_{(1,27)}=.224, p=.64\right)$ in nonce words. There were no other significant effects for nonce words. The effect of applied rule on N250 was not significant for nonce words. Grand average of ERP waveforms of four conditions at four regions is showed in the Figure 2.

\section{DISCUSSION \& CONCLUSION}

This study examines whether words and nonce words go through different GPC during word recognition. In addition to the behavioral analyses, this study focused on N250 to observe phonological activation during the visual recognition of Korean words and nonce words.

Behavioral results revealed that the ability to judge the correct pronunciation in nonce words, where spelling-to-sound was inconsistent, was significantly lower than the ability to judge the pronunciation in words. This observation was confirmed in both accuracy of judgment and RTs. In particular, the accuracy was significantly higher and the RTs were significantly shorter in the judgments for words than for nonce words. The accuracy was significantly higher and the RTs were significantly shorter in the judgments for correctly applied rules than for incorrectly applied rules.

The results of this study are similar with a previous report (Yi, 1996), which indicates that when people read familiar words, they 

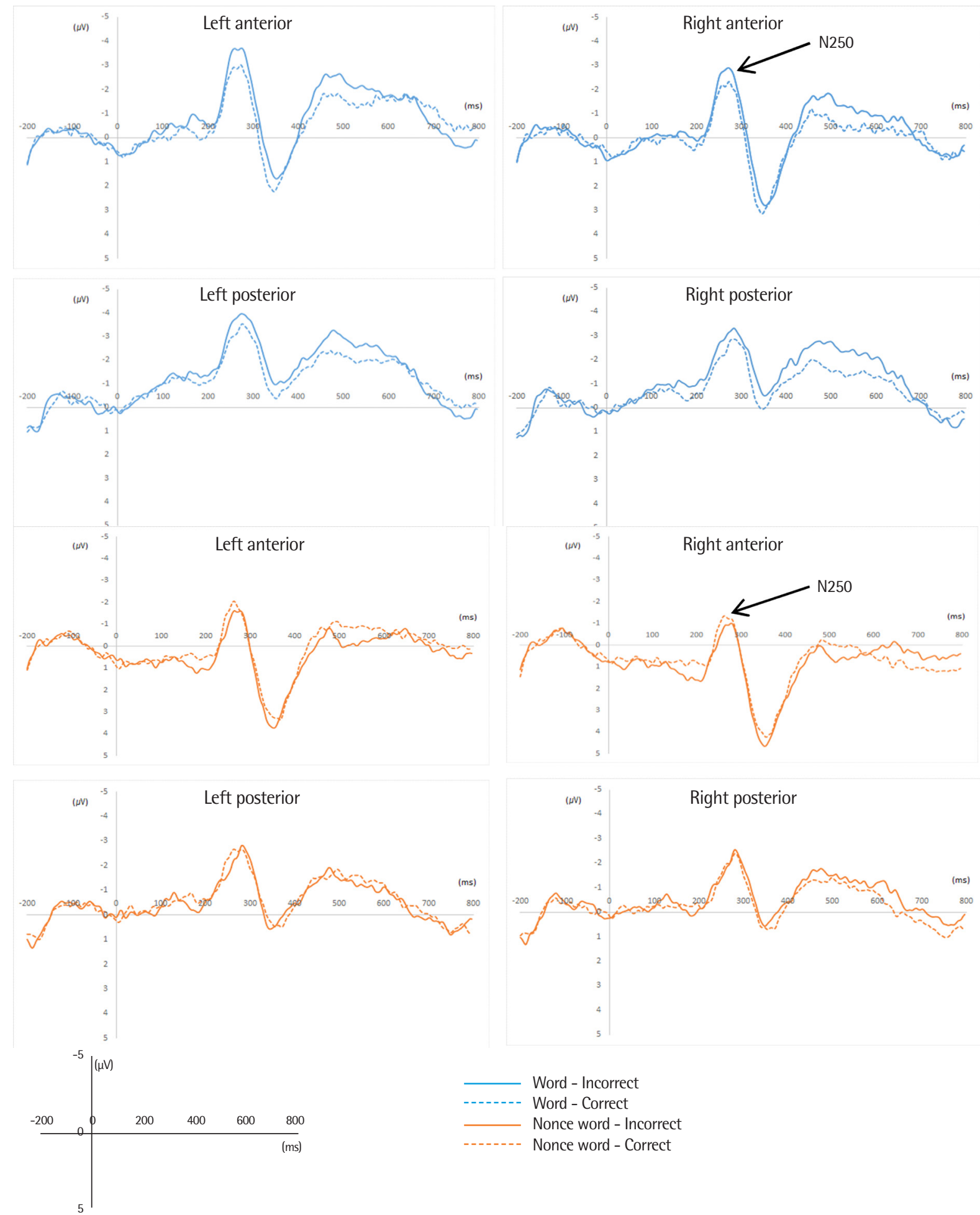

Word - Incorrect

Word - Correct

Nonce word - Incorrect

Nonce word - Correct

Figure 2. Grand-average event-related potential (ERP) waveforms of four conditions at four regions: word with incorrect pronunciation with unapplied phonological rules (consistent spelling-to-sound), word with correct pronunciation with applied phonological rules (inconsistent spelling-to-sound), nonce word with incorrect pronunciation with unapplied phonological rules (consistent spelling-to-sound), nonce word with correct pronunciation with applied phonological rules (inconsistent spelling-to-sound). 
do not go through the GPC route. However, when they encounter a new word, they go through the GPC route to connect the spelling-to-sound. Thus, the accuracy rate is lower and the reaction time is longer with incorrect pronunciation in nonce words than in words. This demonstrates the dual route model (Coltheart, 2006). Furthermore, it implies that the $500 \mathrm{~ms}$, which was provided for the visual recognition of words in the experiment, is not a sufficient time to convert grapheme to phoneme and then to apply the phonological rules. In fact, in experiments 1 and 2 of a research by Yi (1996), the mean time of reading words was $508 \mathrm{~ms}$ and the one for nonce words was $627 \mathrm{~ms}$, which is longer than the $500 \mathrm{~ms}$ provided in this study.

The 2-way interactions in accuracy rate show that abilities to judge words and nonce words where rules are correctly applied were significantly better than the abilities to judge the words and nonce words where rules are incorrectly applied. There was a large difference in participants' abilities to judge the words and nonce words with incorrect pronunciations. This is the same with a report by Lee and Kim (2003) which showed that large differences appear between the pronunciation among participants when reading the words by applying phonological rules, and greater differences appear in the nonce words than in the words. In addition, as presented in the word reading study of Kwon et al. (2015), it may have been due to the fact that both forms of pronunciation may be used in everyday life. In particular, for the purpose of conveying the spelling of new words, it is common practice to pronounce the word with the exact sound of the spelling rather than changing the sounds by applying the phonological rules. The fact that there may be two acceptable pronunciations may impede participants' ability to choose the right answer when determining the 'correct pronunciation'.

When the rules were applied, the difference of RTs between words and nonce words was $53.2 \mathrm{~ms}$ and when the rules were not applied, it was $64.3 \mathrm{~ms}$. This shows no significant 2 -way interactions effect between applied rules and word category. Based on the dual route theory of Coltheart (2006), nonce words need more time to process the GPC than words. This could be used as baseline data in subsequent studies by comparing the performance of adults with disabilities.

N250 is a sensitive ERP which shows a small waveform under a consistent condition of phoneme or grapheme (Grainger, Kiyonaga, \& Holcomb, 2006). The smaller waveform appears when the prime target is phonologically consistent (Ashby, Sanders, \& Kingston, 2009; Kwon, Lee, \& Nam, 2011; Newman \& Connolly, 2004). In this study, there was a significantly smaller waveform of N250 in correct pronunciation compared to incorrect pronunciation of the words. The result reveals that after visual word recognition, participants expect to hear the phonemic forms in which rules are applied (inconsistent in spelling-to-sound). This suggests that words are stored in phonemic forms in the mental lexicon. More specifically, when processing the words, the orthographic information is transmitted directly to the mental lexicon without going through the GPC route. Therefore, when participants see the lexical word '윤리(Yoon-li)', instead of converting the grapheme to phoneme, they process the word in phonemic form /Yool-li/, which makes smaller activation on N250.

In contrast, nonce words do not have significant differences in N250 regardless of applied rules. According to the dual route theory (Coltheart, 2006), nonce words go through the process of GPC before reaching the mental lexicon. For example, when participants read the nonce word '진라(Jin-la)' which is not stored in the lexicon, they first have to convert the grapheme to the corresponding phoneme /Jin-la/ and then change the phoneme to the correct sound /Jil-la/ by applying the phonological rule. Therefore, because processing of the GPC and applying of the rules coincide, participants come to expect two possible sounds at the same time. This results in no significant difference in N250. This may explain why the participants were slower and less accurate when judging the pronunciation of nonce words.

Our study provides neurological evidence for the dual route model of reading and writing of Döhla and Heim (2016)'s study. In particular, GPC is critical in visual word recognition, especially when processing unfamiliar words in Korean. Because familiar words are stored as phonemic forms in lexicons, words are automatically recognized as phonemes which are converted by phonological rules in visual word recognition. However, nonce words stay in the phonological buffer after GPC and cause the delay of recognition. Even when participants gave the correct answer on judging the pronunciation of nonce words, it seems that they did not feel awkwardness about both correct and incorrect pronuncia- 
tions.

We intended to analyze phonological processing when applying the phonological rules and to examine the related ERP component. This is the first study using both visual and auditory stimuli and we could present various views about phonological processing which progressed from previous reports on the Korean language (Kwon et al., 2011; Kwon et al., 2016; Lee \& Kim, 2003; Park, 1999). This complex task made overlaps between ERP waveforms. Therefore it was difficult to detect the pure component of GPC. Holcomb and Anderson (1993) explained that the waveforms of auditory targets are influenced continuously by the waveforms caused by the visual prime. Further studies should be designed more deliberately in order to examine the phonological activation precisely. And future research on comparing various groups is also needed.

The results of our study could contribute to understand a part of the basic mechanism in phonological processing in the Korean language. This will be useful for research into word recognition and language development in children, as well as word recognition in older adults with impaired reading and writing ability. It may also be useful to neurologically verify the effect of therapy on reading disability groups. Although various studies about the methods and efficacy of therapeutic interventions for reading words with phonological rules have been conducted (Ahn et al., 2009; Kim \& Lee, 2008; Lee \& Kim, 2006), there is still much more to be revealed in this field. We hope this study could provide a part of neurological basis for the research and development of treatment in reading disabilities.

\section{REFERENCES}

Ahn, S. W., Kim, H. J., Shin, M. S., Seo, Y. K., Kim, D. H., \& Kim, M. K. (2009). A case study of the effects of phonological awareness training on brain activation profiles of a child with reading disabilities. Journal of Speech-Language \& Hearing Disorders, 18(3), 81-97.

Ashby, J., Sanders, L. D., \& Kingston, J. (2009). Skilled readers begin processing sub-phonemic features by $80 \mathrm{~ms}$ during visual word recognition: Evidence from ERPs. Biological Psychology, 80(1), 84-94.

Bonte, M. L., \& Blomert, L. (2004). Developmental dyslexia: ERP correlates of anomalous phonological processing during spoken word recognition. Cognitive Brain Research, 21(3), 360-376.
Cho, H., \& Pyun, S. B. (2015). Characteristics of acquired phonological dyslexia in Korean. Communication Sciences \& Disorders, 20(4), 570-586.

Coltheart, M. (2006). Dual route and connectionist models of reading: an overview. London Review of Education, 4(1), 5-17.

Connolly, J. F., Phillips, N. A., \& Forbes, K. A. (1995). The effects of phonological and semantic features of sentence-ending words on visual eventrelated brain potentials. Electroencephalography and Clinical Neurophysiology, 94(4), 276-287.

Delorme, C., \& Makeig, S. (2004). EEGLAB: An open source toolbox for analysis of single-trial EEG dynamics. Journal of Neuroscience Methods, $134,9-21$.

Döhla, D., \& Heim, S. (2016). Developmental dyslexia and dysgraphia: what can we learn from the one about the other? Frontiers in Psychology, 6, 2045.

Grainger, J., Kiyonaga, K., \& Holcomb, P. J. (2006). The time course of orthographic and phonological code activation. Psychological Science, 17(12), 1021-1026.

Hallahan, D. P., Lloyd, J. W., Kauffman, J. M., Weiss, M. P., \& Martinez, E. A. (2005). Learning disabilities: foundations, characteristics, and effective teaching (3th ed.). Boston, MA: Person.

Holcomb, P. J., \& Anderson, J. E. (1993). Cross-modal semantic priming: a time-course analysis using event-related brain potentials. Language and Cognitive Processes, 8(4), 379-411.

Holcomb, P. J., \& Grainger, J. (2006). On the time course of visual word recognition: an event-related potential investigation using masked repetition priming. Journal of Cognitive Neuroscience, 18(10), 1631-1643.

Kim, H. S. (2005). General Language Statistics 2. Seoul, Korea: National Institute of Korean Language

Kim, S. J., \& Lee, J. Y. (2008). The effects of applied multisensory treatment on phonological process of reading pronunciation for the middle school students with mental retardation. Korean Journal of Communication \& Disorders, 13(1), 26-43.

Kwon, Y., Choi, S., \& Lee, Y. (2016). Early use of orthographic information in spoken word recognition: event-related potential evidence from the Korean language. Psychophysiology, 53(4), 544-552.

Kwon, Y., Lee, Y., \& Nam, K. (2011). The different P200 effects of phonological and orthographic syllable frequency in visual word recognition in Korean. Neuroscience Letters, 501(2), 117-121.

Kwon, Y., Nam, Y., \& Lee, Y. (2015). The effect of the phonological information in the Korean visual word recognition: an event related potential study. The Journal of Linguistic Science, 75, 23-42. 
Landerl, K., Wimmer, H., \& Frith, U. (1997). The impact of orthographic consistency on dyslexia: a German-English comparison. Cognition, 63(3), 315-334.

Lee, H. S., \& Kim, J. O. (2003). The effects of ease with phonological rules applicability on phonological processing of Korean words and nonwords. Korean Journal of Experimental Psychology, 15(3), 425-454.

Lee, J. Y., \& Kim, J. M. (2006). Effect of combined word recognition and reading comprehension intervention on reading pseudowords for school-aged children with reading disabilities. Korean Journal of Communication \& Disorders, 11(3), 64-81.

McPherson, W. B., Ackerman, P. T., Holcomb, P. J., \& Dykman, R. A. (1998). Event-related brain potentials elicited during phonological processing differentiate subgroups of reading disabled adolescents. Brain and Language, 62(2), 163-185.

Moura, O., Moreno, J., Pereira, M., \& Simões, M. R. (2015). Developmental dyslexia and phonological processing in European Portuguese orthography. Dyslexia, 21(1), 60-79.

Newman, R. L., \& Connolly, J. F. (2004). Determining the role of phonology in silent reading using event-related brain potentials. Cognitive Brain Research, 21(1), 94-105.

Park, K. S. (1999). Is phonology obligatory in visual access to word meaning? Negative evidence for associative homophone priming in Korean word naming task. Korean Journal of Experimental and Cognitive Psychology, 11(1), 17-28.

Picton, T. W., Bentin, S., Berg, P., Donchin, E., Hillyard, S. A., Johnson, R., ...
\& Taylor, M. J. (2000). Guidelines for using human event-related potentials to study cognition: recording standards and publication criteria. Psychophysiology, 37(2), 127-152.

Saralegui, I., Ontañón, J. M., Fernandez-Ruanova, B., Garcia-Zapirain, B., Basterra, A., \& Sanz-Arigita, E. J. (2014). Reading networks in children with dyslexia compared to children with ocular motility disturbances revealed by fMRI. Frontiers in Human Neuroscience, 8, 936.

Schneider, W., Eschman, A., \& Zuccolotto, A. (2002). E-Prime (Version 2.0). [Computer software and manual]. Pittsburgh, PA: Psychology Software Tools Inc.

Wagner, R. K., \& Torgesen, J. K. (1987). The nature of phonological processing and its causal role in the acquisition of reading skills. Psychological Bulletin, 101(2), 192-212.

Weber-Fox, C., Spencer, R. M., Spruill, J. E., \& Smith, A. (2004). Phonologic processing in adults who stutter. Journal of Speech, Language, and Hearing Research, 47(6), 1244-1258.

Yi, K. O. (1996). Phonological rules in oral reading of Korean. Korean Journal of Experimental \& Cognitive Psychology, 8(1), 1-23.

Yoon, H. J., Kim, M., \& Pae, S. (2011). The decoding skills of school-aged children with poor reading skills. Korean Journal of Communication \& Disorders, 16(4), 582-596.

Ziegler, J. C., Benraiss, A., \& Besson, M. (1999). From print to meaning: an electrophysiological investigation of the role of phonology in accessing word meaning. Psychophysiology, 36(6), 775-785. 


\section{국문초록}

\section{한국어 불규칙 단어 재인 시 표기-음운변환 처리과정: 사건관련전위 연구}

최서진 · 심현섭

이화여자대학교 언어병리학과

배경 및 목적: 한국어는 표층표기체계 문자임에도 불구하고 음운규칙을 적용해야 하는 불규칙 단어들이 있어 음운경로가 손상된 난 독증 아동들이 읽기에 어려움을 겪는다. 본 연구에서는 이러한 불규칙 단어재인 시, 표기-음운변환 과정에서의 의미 단어와 무의미 단 어의 차이를 보고자 음운처리 과정을 보여주는 N250 파형을 분석하였다. 나아가 이중경로모형 가설을 바탕으로 표기-음운변환 경로 의 활성화 과정을 설명하고자 하였다. 방법: 한국어를 모국어로 사용하는 28 명의 성인을 대상으로 음운판단 과제를 시행하였다. 피험 자들은 시각단어재인 후 연이어 들려주는 청각 단어와의 음운비교를 통해 음운규칙이 올바르게 적용되었는지 여부를 판단하였으며, 과제를 시행되는 동안 정반응률과 반응시간을 측정하였고 뇌전도 녹화 또한 진행되었다. 결과: 무의미단어에서 의미단어에 비해 N250 효과가 더 크게 나타났다. 의미 단어 내에서는 음운규칙을 적용하지 않았을 때 적용했을 때보다 유의미한 N250 효과가 나타났으나, 비 단어 내에서는 유의미한 결과가 나타나지 않았다. 논의 및 결론: 한국인 성인의 경우 의미단어와 무의미단어재인 시 서로 다른 음운경 로를 활성화시킨다는 점을 시사하며 이는 이중경로모형을 신경학적으로 뒷받침한다. 자동적으로 음운변환이 일어나는 의미단어재인 과 달리 무의미단어재인 시에는 표기-음운변환 과정을 거치게 된다.

핵심어: 한국어 단어재인, 음운규칙, N250, 음운처리, 표기-음운변환, 이중경로모형, 난독증

본 연구는 한국연구재단 2018년 BK21 플러스의 지원을 받아 진행되었음(NRF-1-2019-0405-001-1).

\section{참고문헌}

김한샘(2005). 현대 국어 사용 빈도 조사 2. 국립국어원 (서울: 원화인쇄)

\section{ORCID}

최서진(https://orcid.org/0000-0002-7960-2607); 심현섭(https://orcid.org/0000-0002-4710-3678) 